\title{
Evaluation of mobile emissions contributions to Mexico City's emissions inventory using on-road and cross-road emission measurements and ambient data
}

\author{
M. Zavala ${ }^{1}$, S. C. Herndon ${ }^{2}$, E. C. Wood $^{2}$, T. B. Onasch ${ }^{2}$, W. B. Knighton ${ }^{3}$, L. C. Marr ${ }^{4}$, C. E. Kolb ${ }^{2}$, and L. T. Molina ${ }^{1}$ \\ ${ }^{1}$ Molina Center for Energy and the Environment, La Jolla, California and Massachusetts Institute of Technology, \\ Cambridge, Massachusetts, USA \\ ${ }^{2}$ Center for Atmospheric and Environmental Chemistry, Center for Cloud and Aerosol Chemistry, Aerodyne Research Inc., \\ Billerica, Massachusetts, USA \\ ${ }^{3}$ Department of Chemistry and Biochemistry, Montana State University, Bozeman, Montana, USA \\ ${ }^{4}$ Department of Civil and Environmental Engineering, Virginia Tech, Blacksburg, Virginia, USA
}

Received: 10 February 2009 - Published in Atmos. Chem. Phys. Discuss.: 10 March 2009

Revised: 14 July 2009 - Accepted: 17 August 2009 - Published: 2 September 2009

\begin{abstract}
Mobile emissions represent a significant fraction of the total anthropogenic emissions burden in the Mexico City Metropolitan Area (MCMA) and, therefore, it is crucial to use top-down techniques informed by on-road exhaust measurements to evaluate and improve traditional bottom-up official emissions inventory (EI) for the city. We present the measurements of on-road fleet-average emission factors obtained using the Aerodyne mobile laboratory in the MCMA in March 2006 as part of the MILAGRO/MCMA-2006 field campaign. A comparison of our on-road emission measurements with those obtained in 2003 using essentially the same measurement techniques and analysis methods indicates that, in the three year span, NO emission factors remain within the measured variability ranges whereas emission factors of aldehydes and aromatics species were reduced for all sampled driving conditions.

We use a top-down fuel-based approach to evaluate the mobile emissions from the gasoline fleet estimated in the bottom-up official 2006 MCMA mobile sources. Within the range of measurement uncertainties, we found probable slight overpredictions of mean EI estimates on the order of $20-28 \%$ for CO and $14-20 \%$ for NO. However, we identify a probable EI discrepancy of VOC mobile emissions between 1.4 and 1.9; although estimated benzene and toluene mobile emissions in the inventory seem to be well within the uncertainties of the corresponding emissions estimates. Aldehydes mobile emissions in the inventory, however, seem to be un-
\end{abstract}

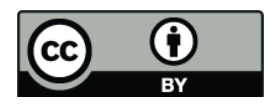

Correspondence to: M. Zavala (miguelz@mce2.org) derpredicted by factors of 3 for $\mathrm{HCHO}$ and 2 for $\mathrm{CH}_{3} \mathrm{CHO}$. Our on-road measurement-based estimate of annual emissions of organic mass from $\mathrm{PM}_{1}$ particles suggests a severe underprediction (larger than a factor of 4 ) of $\mathrm{PM}_{2.5}$ mobile emissions in the inventory.

Analyses of ambient $\mathrm{CO}, \mathrm{NO}_{\mathrm{x}}$ and $\mathrm{CO} / \mathrm{NO}_{\mathrm{x}}$ concentration trends in the MCMA indicate that the early morning ambient $\mathrm{CO} / \mathrm{NO}_{\mathrm{x}}$ ratio has decreased at a rate of about $1.9 \mathrm{ppm} / \mathrm{ppm} / \mathrm{year}$ over the last two decades due to reductions in $\mathrm{CO}$ levels rather than by $\mathrm{NO}_{\mathrm{x}}$. These trends, together with the analysis of fuel sales and fleet size, suggest that the relative contribution of diesel vehicles to overall $\mathrm{NO}_{\mathrm{x}}$ levels has increased over time in the city. Despite the impressive increase in the size of the vehicle fleet between 2000 and 2006, the early morning ambient concentrations of $\mathrm{CO}$ and $\mathrm{NO}_{\mathrm{x}}$ have not increased accordingly, probably due to the reported low removal rates of older vehicles, which do not have emissions control technologies, and partially due to the much lower emissions from newer gasoline vehicles. This indicates that an emission-based air quality improvement strategy targeting large reductions of emissions from mobile sources should be directed towards a significant increase of the removal rate of older, highly-polluting, vehicles.

\section{Introduction}

As in many urban areas, mobile sources in the Mexico City metropolitan area (MCMA) are responsible for a significant fraction of fine particulate matter $(\mathrm{PM}), \mathrm{CO}_{2}, \mathrm{CO}, \mathrm{NO}_{\mathrm{x}}$, $\mathrm{NH}_{3}$, and volatile organic compounds (VOCs) emitted to the

Published by Copernicus Publications on behalf of the European Geosciences Union. 
atmosphere (Molina et al., 2007). Many of these pollutants are critical precursors of photochemical ozone and secondary organic and inorganic particles, which decisively impact the oxidant levels and aerosol loadings in an urban area. Furthermore, as elsewhere, MCMA mobile emissions have shown to include an array of toxic VOCs and carbonaceous PM compounds (Jiang et al., 2005; Rogers et al., 2006; Zavala et al., 2006; Wöhrnschimmel et al., 2008), directly impacting human health. This suggests that significant human health, ecosystems and climate benefits can be obtained by controlling mobile emission sources, as long as mobile emissionsbased air quality control policies are based on clear understanding and reliable quantification of these emissions.

Mobile source emissions contributions to emissions inventories (EIs) are generally quantified using activity factors, estimated from vehicle census or traffic demand models, and emission factors obtained from vehicle exhaust measurements that are input into individual vehicle or fleet emission models (NARSTO, 2005). However, activity factors (e.g., average kilometers driven per unit time) have an inherent high variability because they have to be specified for various vehicle types under varying vehicle operating conditions. In addition, mobile emission factors constantly evolve in any given urban area due to changes in the characteristics of the vehicle fleet, including vehicle age distribution, engine and drive train technology and emission control devices (Popp et al., 1999). On-road vehicle emission measurements have also revealed a strong dependence on vehicle speed and engine load (Pierson et al., 1996; Kean et al., 2003; Jazcilevich et al., 2007). Other factors, including fuel composition, ambient conditions, driving modes and maintenance practices, also affect the variability of on-road mobile emissions within and across vehicles types (e.g., Cadle et al., 2007).

Within the past two decades several modeling, dynamometer, and on-road measurement techniques have been developed to estimate mobile emissions (e.g., Whitfield et al., 1998; Kirchstetter et al., 1999; Bishop et al., 1989; Cadle et al., 2002; Kolb et al., 2004). These methods have resulted in significantly improved knowledge of the magnitude and variability of key vehicle class emission factors for a range of exhaust species. For example, the general differences between the emission characteristics of diesel and gasoline vehicle fleets have been established for some urban areas. However, given the rapid evolution of vehicle fleets, particularly for urban areas in developing regions, and the variability of local vehicle fleet characteristics, emissions factors are generally not directly transferable from one urban area to another (Zavala et al., 2009a). When non-local emission factors are used and sources of variability are not appropriately recognized and addressed, the resulting emissions inventories may have large uncertainties.

Quantification of EI uncertainties is useful to identify problems and set improvement priorities. Quantitative evaluations of mobile emissions inventories uncertainties involve the use of uncertainty-propagation and sensitivity analyses for both activity and emission factors (e.g., Zhao and Frey, 2004; Frey and Zhao, 2004). However, bottom-up EI estimates can also be evaluated using measurement-based topdown analyses. Two relatively simple techniques that allow top-down evaluation of mobile source EIs are the fuel-based emission estimates and trend analyses of ambient measurements of pollutants that are emitted predominantly by mobile sources.

First introduced by Singer and Harley (1996), fuel-based emissions estimation techniques use fuel sales data and onroad measurements of fleet-average emission factors that are normalized by the mass of fuel burned. The technique has been used extensively in urban areas, including Los Angeles (Singer and Harley, 2000), Nashville, (Harley et al., 2001), Denver (Pokharel et al., 2002) and Houston (McGaughey et al., 2004). The fuel-based technique has also been applied previously in Mexico City to evaluate the 1998 mobile emissions inventory (Schifter et al., 2005), suggesting large EI uncertainties.

Trend analyses of ambient pollutant measurements have proved to be useful for the evaluation of emissions from mobile sources. Fujita et al. (1992) was the first to show that the $\mathrm{CO} / \mathrm{NO}_{\mathrm{x}}$ ratios measured during the morning traffic peak hours provided an accurate indication of the emission ratios of these species for on-road vehicles in California. Parrish et al. (2002) showed that, with proper data filtering and a careful selection of measurement sites, ambient measurements could reflect the temporal trends of $\mathrm{CO}$ and $\mathrm{NO}_{\mathrm{x}}$ emissions, as well as the $\mathrm{CO} / \mathrm{NO}_{\mathrm{x}}$ ratio from on-road vehicle emissions. Since mobile emissions represent a significant fraction of the total anthropogenic emissions burden in Mexico City, these fuel-based and ambient trend analyses techniques can be valuable tools to evaluate current official MCMA EI mobile emissions estimates.

In this work we present the measurements of on-road fleetaverage emission factors obtained using the Aerodyne mobile laboratory in Mexico City in March 2006. We use the measured fuel-based emission factors to estimate fleet average emissions for the gasoline vehicle fleet. We use our onroad results and a review of past and recent cross-road remote sensing emission studies to evaluate the mobile emissions of $\mathrm{CO}, \mathrm{NO}_{\mathrm{x}}, \mathrm{PM}_{2.5}$, total volatile organic compound (VOC), and selected specific VOCs estimated in the 2006 official emissions inventory in the city. Finally, we compare ambient $\mathrm{CO}, \mathrm{NO}_{\mathrm{x}}$ and $\mathrm{CO} / \mathrm{NO}_{\mathrm{x}}$ concentration trends with the corresponding mobile emission estimates from the MCMA emissions inventory and discuss the probable impacts of changes in vehicle fleet characteristics on these trends.

\section{Experimental methods}

The Aerodyne mobile laboratory was deployed in Mexico City during March of 2006 as part of the MCMA2006/MAX-Mex/MILAGRO field campaigns (Molina et al., 
2008). The mobile laboratory contained an extensive set of research grade, real-time (1-2 s measurement times) trace gas and fine particulate matter instruments and was deployed to various representative urban and boundary sites across the MCMA. In addition to these stationary site measurements, the fast time response instrumentation was also used during mobile lab transits between sites to obtain on-road vehicle emissions data. Table 1 describes a portion of the instrumentation on-board the mobile laboratory, the on-road pollutants measured, as well as the detection levels of the relevant instruments. The mobile laboratory also fielded a Global Positioning System (GPS), an anemometer, and a video camera that helped determine traffic flow speeds, exhaust plume sampling conditions and nearby vehicle types, respectively. The mobile laboratory's velocity and acceleration were measured and recorded continuously during the experiment along with meteorological parameters, including pressure, temperature, and relative humidity.

This work does not include results obtained using the chase technique (e.g., Herndon et al., 2005; Zavala et al., 2006, 2009a), which focuses on a series of selected individual vehicles within a given vehicular class. The mobile laboratory measurements reported here focused on obtaining fleet average emission factors by processing randomly intercepted vehicle plumes from the surrounding traffic, which can be classified by driving modes set by the predominant traffic speed range, as described in detail in Zavala et al. (2006). Briefly, we define driving modes as "Stop and Go" (SAG) for situations when the mobile laboratory was immersed in very heavy traffic, with a speed range of $16( \pm 8) \mathrm{km} / \mathrm{hr}$ for 5 min or more; "Traffic" (TRA) for heavy traffic conditions with a speed range of $40( \pm 16) \mathrm{km} / \mathrm{hr}$, for 5 or more minutes; and "Cruise" (CRU) for moderate traffic conditions moving at speeds of $56 \mathrm{~km} / \mathrm{hr}$ or higher, for $5 \mathrm{~min}$ or more. In the fleet average sampling mode, emission ratios were obtained by analyzing the periods in which the emission signatures from surrounding vehicles were sufficiently mixed by the time they were sampled by the mobile lab. By moving slightly slower than the surrounding traffic, the mobile laboratory was ensured of sampling the exhaust plumes produced by a wide variety of passing vehicles while the readings from the anemometer were used to filter out possible "self sampling" periods. In addition, the images obtained with the video camera allowed observation and classification of nearby vehicles. Supplemental real-time data log notes entered by the researchers on-board the mobile laboratory identified potential off-road point and area pollutant sources as well as onroad traffic conditions, thus allowing us to distinguish possible sources of pollutants other than nearby mobile sources. These tools, together with the analyses of the species signals measured with the multiple, synchronized, instruments on board the mobile laboratory, are used to characterize both possible background pollutant sources and nearby gasoline and/or diesel vehicle emissions. Further details on the data analysis technique and filtering criteria for self-sampling and influences from non-combustion sources are described elsewhere (Zavala et al., 2006).

The spatial distributions of mobile emissions within a city may be complex due to inhomogeneous geographical distributions of the vehicle fleet characteristics (e.g., predominance of newer vehicles in affluent neighbourhoods). In this study these effects are not explicitly treated as the onroad measurements were predominantly obtained on multiple high traffic density roads across the city in order to obtain fleet average emissions. Although in our analysis we distinguished between gasoline and diesel emissions, we present only the results for the gasoline vehicle fleet in this work. After filtering the data, a total of 28 gasoline vehicle fleet average sampling intervals (corresponding to a total sampling size of about 2880 SAG, 3480 CRU, and 5280 TRA 1-s sampling valid points) were identified during the analysis of approximately $6.5 \mathrm{~h}$ of on-road data. Note that, due to the nature of these types of experiments, relatively few sampling periods were obtained during the intensive field campaign. However, in the fleet average sampling mode hundreds to thousands of individual exhaust plumes are actually sampled in a given on-road fleet average experiment; so that with proper filtering criteria, the statistics become robust enough to yield fleet average emission characteristics representative of a range of driving conditions (Jiang et al., 2005; Zavala et al., 2009a).

The analysis technique is based on the characterization of possible background pollutant sources as well as the intercepted gasoline and/or diesel vehicle emission plumes using the highly sensitive, real-time instrumentation on-board the mobile laboratory. All identified exhaust plume pollutant species are correlated with the excess (above background) exhaust plume $\left(\mathrm{CO}+\mathrm{CO}_{2}\right)$ concentrations, allowing molar emission ratios to be computed for each measured exhaust pollutant. Fuel-based emission factors can readily be computed from the observed molar emission ratios assuming fuel carbon combustion is well approximated by the measured excess plume of $\mathrm{CO}+\mathrm{CO}_{2}$ (as confirmed by the relatively low concentrations of measured plume VOC species), a typical value of 54.1 moles of carbon per liter of gasoline and a fuel density of 756 grams/liter. The fuel-based emission factors obtained in the fleet average operational sampling mode are appropriate to use for comparison with mobile emissions measured with other high sampling volume techniques such as cross-road remote sensing.

\section{Results and discussions}

\subsection{Mobile laboratory on-road results}

The measured fuel-based emission factors for gases and particles sampled in fleet average mode for the gasoline vehicle fleet during March of 2006 are summarized by driving mode in Table 2. In this table the emission factors are compared 
Table 1. Instrumentation on board the Aerodyne mobile laboratory used for on-road emission measurements during the MCMA-2006 field campaign ${ }^{\mathrm{a}}$.

\begin{tabular}{lll}
\hline Instrumentation & Measures & $\begin{array}{l}\text { Detection } \\
\text { Limit }\end{array}$ \\
\hline $\begin{array}{l}\text { Proton Transfer Reaction Mass } \\
\text { Spectrometer (PTR-MS) }\end{array}$ & $\begin{array}{l}\text { acetaldehyde, benzene, } \\
\text { toluene, etc. }\end{array}$ & $1-5 \mathrm{ppb}$ \\
\hline & $\mathrm{CO}$ & $1 \mathrm{ppb}$ \\
Tunable Infrared Laser Differential & $\mathrm{NO}_{2}$ & $700 \mathrm{ppt}$ \\
Absorption Spectroscopy (TILDAS) & $\mathrm{H}_{2} \mathrm{CO}$ & $1.2 \mathrm{ppb}$ \\
& $\mathrm{C}_{2} \mathrm{H}_{4}$ & $800 \mathrm{ppt}$ \\
\hline & $\mathrm{Nitrate}$ & $0.01 \mu \mathrm{g} \mathrm{m}^{-3}$ \\
& $\mathrm{Sulfate}^{-3}$ \\
Aerosol Mass Spectrometer (AMS) & Ammonium & $0.01 \mu \mathrm{g} \mathrm{m}^{-3}$ \\
& $\mathrm{Organics}^{-3}$ & $0.12 \mu \mathrm{g} \mathrm{m}^{-3}$ \\
& $\mathrm{Chloride}^{-3}$ & $0.17 \mu \mathrm{g} \mathrm{m}^{-3}$ \\
\hline Non-Dispersive Infrared instruments & $\mathrm{CO}_{2}$ & $0.02 \mu \mathrm{g} \mathrm{m}^{-3}$ \\
(NDIR) unit (LICOR) & & $0.2 \mathrm{ppm}^{2}$ \\
\hline Chemiluminescence & $\mathrm{NO}_{\mathrm{x}}, \mathrm{NO}_{\mathrm{y}}$ & $0.4 \mathrm{ppb}^{2}$ \\
\hline
\end{tabular}

a The detection limits quoted are for a signal-to-noise value of 2 and a 1-s measurement.

with corresponding emission factors obtained in 2003 during the MCMA-2003 field campaign (Molina et al., 2007). We do not present estimates for the $\mathrm{CO}$ emission factors for 2003 because during this campaign the time response of the instrument measuring $\mathrm{CO}$ was not fast enough to characterize individual exhaust plumes (Jiang et al., 2005). Therefore, to allow a direct comparison between 2003 and 2006 measurements, the emission factors presented in Table 2 for the 2006 measurements are estimated using only excess $\mathrm{CO}_{2}$ as the correlating species in the exhaust plume, as it was done with the 2003 measurement data (Zavala et al., 2006). Based on the $2006 \mathrm{CO}$ measurements, this assumption overestimates the calculated emission factors by about $5-10 \%$ because the measured emissions levels of exhaust plume $\mathrm{CO}$ and VOCs are small compared to the levels of emitted $\mathrm{CO}_{2}$ (i.e., generally $>90 \%$ of fuel carbon is emitted as $\mathrm{CO}_{2}$ ). However, except for the comparison with 2003 measured fleet-average emission factors, we use emission factors obtained using the sum of above background exhaust plume of $\mathrm{CO}+\mathrm{CO}_{2}$ to normalize pollutant emissions for fuel consumption rates for the fuel-based evaluation of the MCMA mobile EI and cross technique data comparisons in subsequent sections in this paper.

From Table 2 it is difficult to infer any statistically significant changes between the MCMA on-road NO emissions measured in 2003 and 2006 because the observed changes are clearly within the observed variability ranges. As shown later, this is consistent with the observed variability changes in early-morning ambient concentrations of NO in this period. Figure 1 shows a comparison of on-road emission ratios

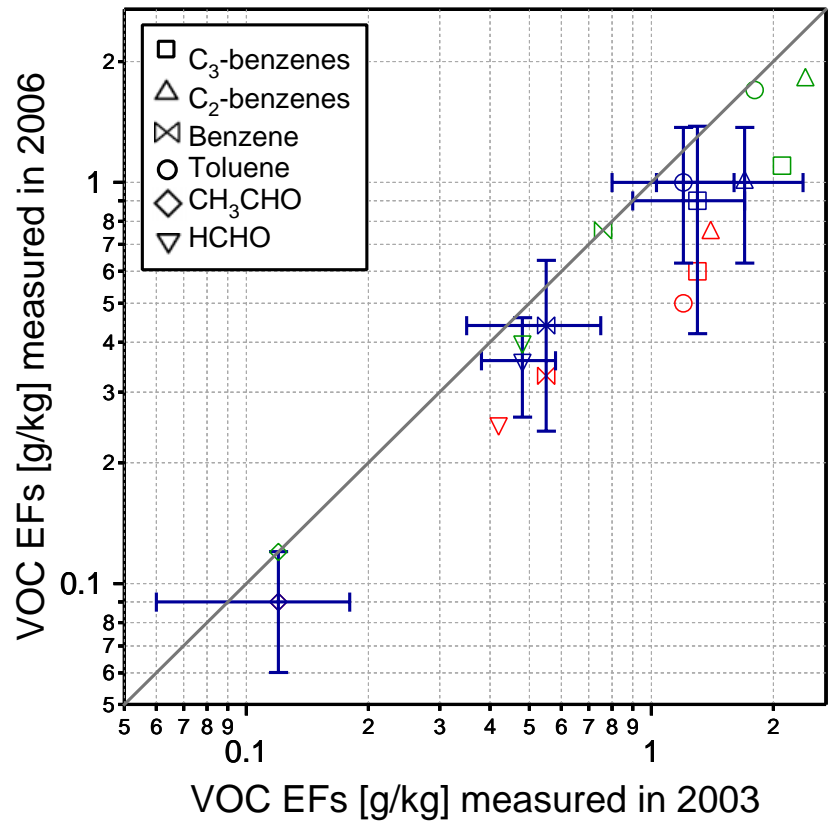

Fig. 1. Comparison of on-road fuel based emission factors (EFs, $\mathrm{g} / \mathrm{kg}$ ) of various VOC pollutants measured in 2003 and 2006 with the ARI mobile laboratory in Mexico City for SAG (green), TRA (blue) and CRU (red) driving conditions. Error bars are shown for TRA driving conditions and represent one standard deviation of the measured values. 
Table 2. Comparison of measured gasoline fleet-average fuel-based mobile emission factors in 2003 and 2006 in Mexico City for various driving modes ${ }^{\mathrm{a}}$.

\begin{tabular}{|c|c|c|c|c|c|c|}
\hline & \multicolumn{2}{|c|}{$\begin{array}{l}\text { SAG } \\
(\mathrm{SD})\end{array}$} & \multicolumn{2}{|c|}{$\begin{array}{l}\text { TRA } \\
\text { (SD) }\end{array}$} & \multicolumn{2}{|c|}{$\begin{array}{l}\text { CRU } \\
\text { (SD) }\end{array}$} \\
\hline & 2003 & 2006 & 2003 & 2006 & 2003 & 2006 \\
\hline $\mathrm{CO}$ & N/A & $\begin{array}{l}380 \\
(210)\end{array}$ & N/A & $\begin{array}{l}142 \\
(80)\end{array}$ & N/A & $\begin{array}{l}89 \\
(30)\end{array}$ \\
\hline NO & $\begin{array}{l}6.1 \\
(2)\end{array}$ & $\begin{array}{l}6.5 \\
(4)\end{array}$ & $\begin{array}{l}9.6 \\
(4)\end{array}$ & $\begin{array}{l}8.4 \\
(2)\end{array}$ & $\begin{array}{l}9.1 \\
(3)\end{array}$ & $\begin{array}{l}12.4 \\
(6)\end{array}$ \\
\hline $\mathrm{HCHO}$ & $\begin{array}{l}0.48 \\
(0.1)\end{array}$ & $\begin{array}{l}0.40 \\
(0.1)\end{array}$ & $\begin{array}{l}0.48 \\
(0.1)\end{array}$ & $\begin{array}{l}0.36 \\
(0.1)\end{array}$ & $\begin{array}{l}0.42 \\
(0.1)\end{array}$ & $\begin{array}{l}0.25 \\
(0.1)\end{array}$ \\
\hline $\mathrm{CH}_{3} \mathrm{CHO}$ & $\begin{array}{l}0.12 \\
(0.06)\end{array}$ & $\begin{array}{l}0.12 \\
(0.06)\end{array}$ & $\begin{array}{l}0.12 \\
(0.06)\end{array}$ & $\begin{array}{l}0.09 \\
(0.03)\end{array}$ & $\begin{array}{l}0.12 \\
(0.03)\end{array}$ & $\begin{array}{l}0.09 \\
(0.06)\end{array}$ \\
\hline Benzene & $\begin{array}{l}0.76 \\
(0.2)\end{array}$ & $\begin{array}{l}0.76 \\
(0.3)\end{array}$ & $\begin{array}{l}0.55 \\
(0.2)\end{array}$ & $\begin{array}{l}0.44 \\
(0.2)\end{array}$ & $\begin{array}{l}0.55 \\
(0.2)\end{array}$ & $\begin{array}{l}0.33 \\
(0.1)\end{array}$ \\
\hline Toluene & $\begin{array}{l}1.8 \\
(0.5)\end{array}$ & $\begin{array}{l}1.7 \\
(0.9)\end{array}$ & $\begin{array}{l}1.2 \\
(0.4)\end{array}$ & $\begin{array}{l}1.0 \\
(0.4)\end{array}$ & $\begin{array}{l}1.2 \\
(0.5)\end{array}$ & $\begin{array}{l}0.50 \\
(0.2)\end{array}$ \\
\hline $\mathrm{C}_{2}$-benzenes & $\begin{array}{l}2.4 \\
(0.8)\end{array}$ & $\begin{array}{l}1.8 \\
(0.8)\end{array}$ & $\begin{array}{l}1.7 \\
(0.7)\end{array}$ & $\begin{array}{l}1.0 \\
(0.4)\end{array}$ & $\begin{array}{l}1.4 \\
(0.7)\end{array}$ & $\begin{array}{l}0.75 \\
(0.3)\end{array}$ \\
\hline $\mathrm{C}_{3}$-benzenes & $\begin{array}{l}2.1 \\
(0.7)\end{array}$ & $\begin{array}{l}1.1 \\
(0.5)\end{array}$ & $\begin{array}{l}1.3 \\
(0.4)\end{array}$ & $\begin{array}{l}0.90 \\
(0.5)\end{array}$ & $\begin{array}{l}1.3 \\
(0.7)\end{array}$ & $\begin{array}{l}0.60 \\
(0.2)\end{array}$ \\
\hline $\mathrm{C}_{2} \mathrm{H}_{4}$ & N/A & $\begin{array}{l}2.1 \\
(0.5)\end{array}$ & N/A & $\begin{array}{l}2.0 \\
(1)\end{array}$ & N/A & $\begin{array}{l}1.2 \\
(0.3)\end{array}$ \\
\hline $\mathrm{CH}_{3} \mathrm{COCH}_{3}$ & N/A & $\begin{array}{l}0.09 \\
(0.03)\end{array}$ & N/A & $\begin{array}{l}0.06 \\
(0.02)\end{array}$ & N/A & $\begin{array}{l}0.04 \\
(0.02)\end{array}$ \\
\hline $\mathrm{PM}_{1}$ organics & N/A & $\begin{array}{l}0.34 \\
(0.2)\end{array}$ & N/A & $\begin{array}{l}0.20 \\
(0.1)\end{array}$ & N/A & N/A \\
\hline
\end{tabular}

a All units are in g pollutant/kg fuel except for $\mathrm{PM}_{1}$ organics $\left[\mu \mathrm{g} / \mathrm{m}^{3} / \mathrm{ppm}-\mathrm{CO}_{2}\right]$. Emission ratios presented in this table are estimated using excess exhaust $\mathrm{CO}_{2}$ as the correlating species. We consider here $\mathrm{C}_{2}$-benzenes as the sum of xylene isomers, ethylbenzene, and benzaldehyde and $\mathrm{C}_{3}$-benzenes as the sum of $\mathrm{C}_{9} \mathrm{H}_{12}$ isomers and $\mathrm{C}_{8} \mathrm{H}_{8} \mathrm{O}$ isomers. SAG: Stop and Go; TRA: Traffic; CRU: Cruise conditions (see text for details). N/A: Not available, SD: 1 standard deviation.

of VOCs sampled in 2003 and 2006 in Mexico City for various driving conditions using the mobile laboratory; the error bars are the 1-sigma standard deviations of the measurements. Although most of the measured VOC emission factors are within the observed variability ranges, all the VOC species showed lower average fuel-based emission ratios for the two highest speed traffic modes in 2006 compared to 2003. Since the measurements were made using the same instrumentation and measurement mode and were analyzed using the same techniques, the observed systematic emissions decreases strongly suggest a reduction of the on-road gasoline vehicle fleet emission factors of these toxic aromatic and aldehyde species between 2003 and 2006. On average, the temperature and relative humidity during the month-long measurements campaigns in March 2006 and April 2003 did not differ significantly (de Foy et al., 2008) to account for the observed differences. Inspection of individual VOCs emission factors in Fig. 1 also shows a clear dependence of the magnitude of the emission factor on driving conditions. The emission factor reductions seem to be more pronounced for CRU driving conditions between the two campaigns. A similar dependency of VOC emission factors on driving conditions was observed in 2005 on-road measurements in Mexicali (Zavala et al., 2009a).

\subsection{Comparison of on-road and cross-road (remote sensing) results}

To put our results in context, it is important to compare our on-road measurements with mobile emission factors obtained using different techniques and in different cities. Figure 2 shows a comparison of the gasoline fleet average fuelbased emission factors presented in this work (using the excess plume of $\mathrm{CO}+\mathrm{CO}_{2}$ ) with those measured by remote sensing in 2000 and 2006 in Mexico City (Schifter et al., 2003, 2008) and in 1999, 2005 and 2006 in several US cities (Bishop and Stedman, 2008). The $\mathrm{CO}$ and $\mathrm{NO}_{\mathrm{x}}$ fuel-based emission factors measured with the Aerodyne mobile laboratory agree remarkably well with those measured in the same year with the remote sensing technique by Schifter et al. (2008) in Mexico City. The emission factors presented by Bishop and Stedman are means estimated using all valid measurements without filtering by fuel type, driving mode, vehicle type, or model year. Still, the 2006 MCMA NO emission factors are similar to the most recent measurements in Denver and Phoenix, whereas all US CO and VOC mobile emissions measurements are significantly lower than the MCMA values. Although gasoline emissions in Mexico City could, in principle, tend to be higher than in US cities because of its location at higher altitude ( $2200 \mathrm{~m}$ a.s.l.), vehicles are generally provided with a mechanism for compensating the effect of altitude on air density. As such, the observed differences are too large to be attributed to the altitude effects and are more likely due to differences in fleet age and to the fraction of vehicles with emission control technologies.

Bishop and Stedman (2008) report that the observed CO reductions in US cities occur in vehicles of all ages and that emissions deterioration rates are near zero for model years newer than 2001 and older than 1990. Between 1999 and 2005, the average annual reductions in $\mathrm{NO}, \mathrm{CO}$, and VOC fuel-based emission factors in the US cities were about $8 \pm 2 \% / \mathrm{yr}, 9 \pm 1 \% / \mathrm{yr}$, and $7 \pm 3 \% / \mathrm{yr}$, respectively. According to Schifter et al. (2009), between 2000 and 2006 the corresponding fuel-based emissions in the MCMA showed much lower $\mathrm{NO}$ and $\mathrm{CO}$ average reductions of about 3.8 and 2.0\%/yr and an increase in VOC fuel-based emissions of about $4.6 \% / y r$. However, the authors indicated that VOC emissions do not show a statistically significant increase in that period when adjusted by Vehicle Specific Power (VSP). This demonstrates that the emission characteristics from the vehicle fleet are significantly different between Mexico City and US cities. The observed differences in fuel-based emissions between Mexico City and US cities are likely related to the older vehicle fleet in Mexico City with higher percentage 


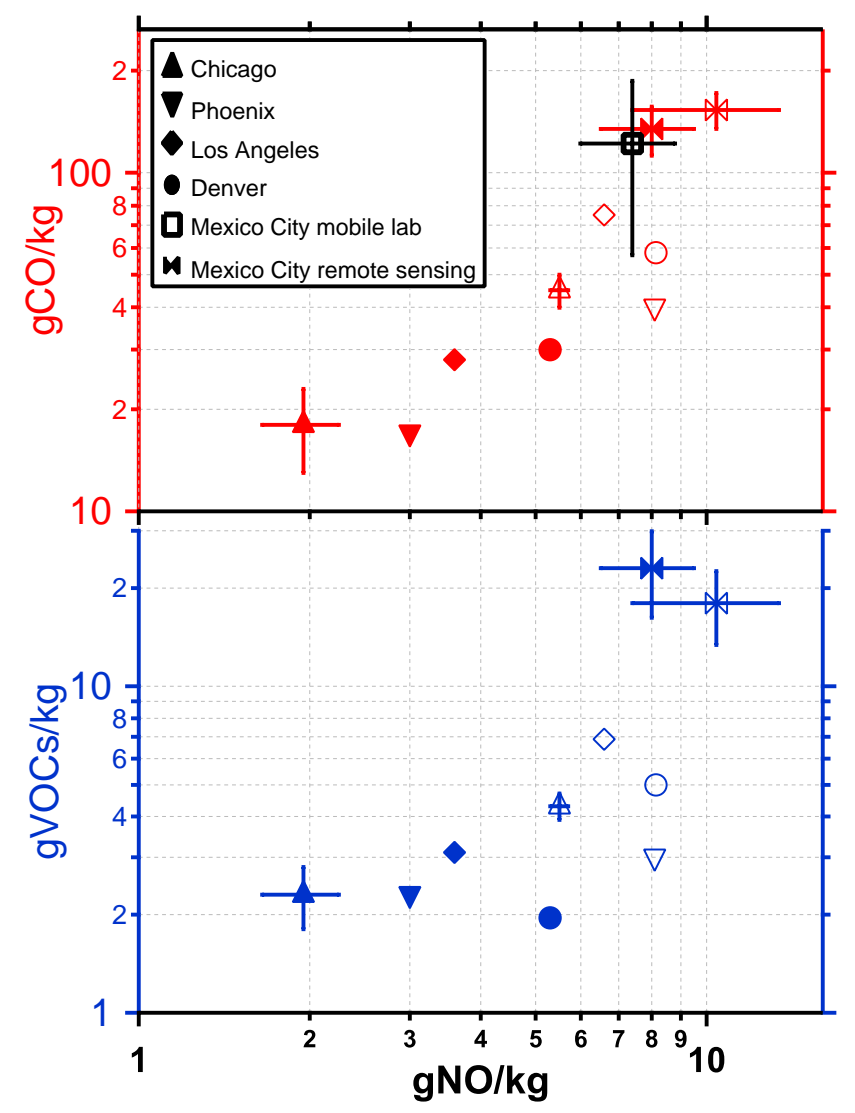

Fig. 2. Comparison of fuel-based emission factors in this work with those measured with remote sensing in 2000 (open symbol) and 2006 (filled symbol) in Mexico City (Schifter et al., 2003, 2008) and in several US cities (Bishop and Stedman, 2008) for CO, NO and hydrocarbons (as propane equivalents). For measurements in US cities, open symbols represent 1999 data whereas filled symbols represent 2005 data (for Denver and Los Angeles) and 2006 data (for Phoenix and Chicago). For US measurements, error bars represent standard errors of the mean plotted for Chicago as representative for all other cities. Error bars for measurements in Mexico City represent one standard deviation.

of vehicles without emission control technology, and to differences in the renewal rates of the US and MCMA vehicle fleets. Vehicle age differences between Mexico City and US cities would have the strongest impact on $\mathrm{CO}$ emissions. In addition, as we will show, the removal rate between 2000 and 2006 for 1990 and older vehicles from the MCMA fleet is very low.

\subsection{Comparison with MCMA EI estimates}

\subsubsection{VOCs emissions}

Top-down evaluation of estimated mobile emission inventories is an important application of measured on-road mobile emission factors. Following Singer and Harley (2000), we have used measured fleet average fuel-based emission factors to estimate annual emissions for the gasoline vehicle fleet. Annual MCMA fuel consumption data was obtained directly from the official emissions inventory (SMA, 2008a). Figure 3 compares the total annual emissions from light-duty gasoline vehicles estimated from 2006 fuel sales records and the fuel-based emission factors from on-road and remote sensing measurements against the corresponding mobile emissions estimates in the official emissions inventory. The comparison indicates an overestimation of about 20 $28 \%$ for $\mathrm{CO}$ and $14-20 \%$ for NO in the inventory compared to our measurement-based estimates. These EI overestimations are, however, well within the range of uncertainties in the on-road and cross-road measurements. We address this issue again in the assessment of ambient trends of $\mathrm{CO}, \mathrm{NO}_{\mathrm{x}}$ and the $\mathrm{CO} / \mathrm{NO}_{\mathrm{x}}$ ratio (Sect. 3.4).

The on-road emission factors obtained with the ARI mobile laboratory did not include measurements of total exhaust VOCs, just the individual VOC species reported in Table 2 and Fig. 1. However, one way to obtain an estimate of possible ranges of total VOC emissions from mobile sources is to investigate the ranges over which the measured cross-road remote sensing VOC/CO mass ratio varies and use this range to scale the measurement-based estimates of $\mathrm{CO}$ on-road emissions. Rather than a point estimate, this approach is only feasible for range estimates of the possible total mobile VOC emissions. Using the reported fuel-based emission factors from Bishop and Stedman (2008), the VOC/CO mass ratio of mobile emissions in US cities increased from $0.09 \pm 0.01$ in 1999 to $0.11 \pm 0.03$ in the $2005-2006$ measurements, whereas in Mexico City this ratio increased from $0.11 \pm 0.03$ in 2000 to $0.17 \pm 0.04$ in 2006 (Schifter et al., 2008).

Even using the wider range of $0.13-0.21$ for the VOC/CO mass ratio measured by remote sensing in 2006 from Schifter et al. (2008), both the total VOC emissions estimated this way and the emissions directly derived from the remote sensing study indicate an overall underprediction of VOC emissions from mobile sources of a factor between 1.4 and 1.9. The emissions estimated from on-road and remote sensing measurements do not include evaporative or cold start emissions. Nevertheless, cold start emissions would not contribute significantly to the fuel-based inventory since not much fuel is consumed in this mode and because the fleet includes a significant number of vehicles without or with malfunctioning catalysts (Singer et al., 1999). Overall, the observed differences between the $\mathrm{CO}, \mathrm{NO}$, and VOC emissions derived by the measured fuel-based emission factors and those estimated in the inventory agree with the scaling factors needed to apply to emission input fields in modeling ozone episodes in Mexico City (Lei et al., 2007). Nevertheless, we note that the comparison of our fuel-based emissions estimate with the VOC mobile EI inventory should be considered as a first approximation because an uncertainty of 40-70\% might not be outside the error bars. Furthermore, the cross-road remote sensing VOC measurements only report approximate total non-methane organics. Therefore, the 


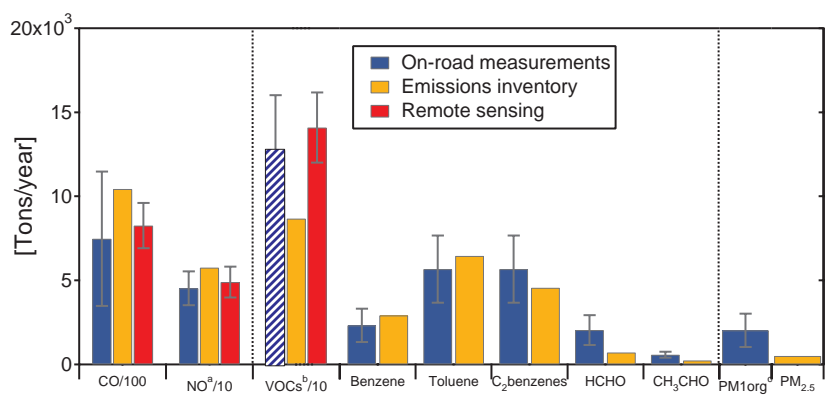

Fig. 3. Comparison of LDGV on-road mobile emissions estimated from this work, from remote sensing (Schifter et al., 2008) and the 2006 - criteria and toxic - emissions inventories (SMA, 2008a, b). The uncertainty bars displayed are standard errors of the means. For clarity, emissions of $\mathrm{CO}, \mathrm{NO}$, and VOCs are divided by factors of 100, 10 and 10, respectively. ${ }^{\mathrm{a}} \mathrm{NO}_{\mathrm{x}}$ emissions in the inventory were assumed $90 \% \mathrm{NO}$ and $10 \% \mathrm{NO}_{2}$ in mass. ${ }^{b}$ Total VOCs emissions from the inventory include evaporative emissions. The corresponding on-road VOC's are inferred rather than measured (see text for details). ${ }^{c}$ Estimated organic mass of particles in the non-refractive $\mathrm{PM}_{1}$ range.

use of the measured remote sensing VOC/CO ratio to calculate VOC emissions provide only an approximate result.

We compared the estimated annual emissions from the individual VOC species with the annual mobile emission estimates for these species from the 2006 toxic emissions inventory for Mexico City (SMA, 2008b). In this comparison benzene and toluene seem to be well within uncertainties of the emissions calculated using our on-road measurements. Although a small underprediction of $\mathrm{C}_{2}$-benzenes is probable, only ethylbenzene and xylene emissions data were available from the emissions inventory so it is possible that other xylenes isomers, not accounted in the inventory, are responsible for the observed difference. Inventory aldehyde emissions, however, seem to be underpredicted by factors of 3 for $\mathrm{HCHO}$ and 2 for $\mathrm{CH}_{3} \mathrm{CHO}$. This underprediction agrees with previous measurement and modeling studies suggesting higher-than-usual aldehydes emissions in Mexico City (Kolb et al., 2004; Zavala et al., 2006; Garcia et al., 2006; Lei et al., 2009). The high levels of aldehydes emissions in Mexico City provide a major source of early morning radicals to "jump-start" each day's photochemistry.

Although the relatively large discrepancy of 1.4-1.9 for total VOCs in the MCMA mobile emissions inventory is not observed in the same proportion in the individual VOC species we measured (it only mass averages to about 1.2), overall the sum of the individual VOC emissions shown in Fig. 3 account only for $\sim 12 \%$ of the total EI VOC emissions. This would indicate that the bulk of the discrepancy would be in the $\sim 90 \%$ of the mass from VOC groups - predominantly alkenes and alkanes - that were not measured in our on-road studies.

\subsubsection{PM emissions}

To estimate the total annual emissions of organic mass in $\mathrm{PM}_{1}$ exhaust particles using the on-road measurements, we first transformed the emission factors of $\mathrm{PM}_{1}$ organic mass reported in Table 2 from $\mu \mathrm{g} / \mathrm{m}^{3}$ (of $\mathrm{PM}_{1 \text { org }}$ ) $/ \mathrm{ppm}-\mathrm{CO}_{2}$ to $\mu \mathrm{g}\left(\right.$ of $\left.\mathrm{PM}_{1 \text { org }}\right) / \mu \mathrm{g}$ (of $\mathrm{CO}$ ) using the molar $\mathrm{CO} / \mathrm{CO}_{2}$ on-road measurements and then scale them to the corresponding annual emissions of CO shown in Fig. 3. Our estimates indicate a probable severe underprediction of $\mathrm{PM}_{2.5}$ emissions from gasoline-powered vehicles in the inventory. The comparison includes only the estimated $\mathrm{PM}_{2.5}$ emissions from gasolinepowered vehicle's exhaust in the inventory. Moreover, the discrepancy (a factor $>4$ ) shown in Fig. 3 between the measured organic mass of $\mathrm{PM}_{1}$ and $\mathrm{PM}_{2.5}$ estimates would be a lower limit estimate because ambient $\mathrm{PM}_{1}$ accounts for $79-83 \%$ in mass of the $\mathrm{PM}_{2.5}$ on average for the month of March at two inner city locations: CENICA and T0 (Querol et al., 2008). This is supported by Stone et al. (2007), who used a chemical mass balance model to estimate that mobile sources, including both diesel and gasoline vehicles, consistently accounted for $\sim 47 \%$ of the MCMA $\mathrm{PM}_{2.5}$ organic carbon.

Since observations of organic aerosols (OA) in Mexico City (e.g., Salcedo et al., 2006) and several parts of the world (Zhang et al., 2007) indicate that OA represent a large fraction of the submicron aerosol mass, it is important to quantify the varying contributions of emission sources in urban areas to the chemically-evolving OA. A comparison of the aircraft OA/CO measurements with the corresponding ratios at surface monitoring sites can be used to evaluate the evolution of organic aerosols (e.g., Kleinman et al., 2008). Using data from 12 research flights during MILAGRO obtained with a High-Resolution Time of Flight Aerosol Mass Spectrometer onboard the NSF/NCAR C-130 aircraft, DeCarlo et al. (2008) reported OA/CO values ranging from $60-87 \mu \mathrm{g} / \mathrm{m}^{3} / \mathrm{ppm}$ (STP) through distances varying from 25 to $575 \mathrm{~km}$ from the city. Using 8 research flights with the G-1 aircraft during MILAGRO, Kleinman et al. (2008) also found similar OA/CO values from the near outflow from Mexico City and a large increase in the ratio when comparing fresh and aged air masses, indicating significant secondary organic aerosol (SOA) production during chemical aging. In contrast, our analysis of early morning (6-9 AM) OA/CO ratios at urban sites (CENICA and T0) during low biomass burning days were consistently between 2.1 and $8.2 \mu \mathrm{g} \mathrm{m}^{-3} \mathrm{pm}^{-1}$ STP during both 2003 and 2006 field campaigns, suggesting a predominant signature of mobile sources on the observed early morning OA/CO ratios.

During MILAGRO-2006 the Aerodyne mobile laboratory spent 11 days at Pico de Tres Padres (PTP), an isolated mountain-top site $(\sim 1 \mathrm{~km}$ a.g.l. $)$ about $5 \mathrm{~km}$ north of the T0 supersite. Because of its location (within the urban area but with very weak local emissions sources), the air masses observed at PTP in the morning were affected only 
by mixed emissions from the MCMA geographic area, and can be considered to be representative of the city (Wood et al., 2009; Herndon et al., 2008). In this unique monitoring site, the diurnal $\mathrm{OA} / \mathrm{CO}$ ratios obtained were in the range $14.9 \pm 7 \mu \mathrm{g} / \mathrm{m}^{3} / \mathrm{ppm}$ (STP). Because this analysis does not differentiate between emission sources (e.g., gasoline vs. diesel), these ratios represent the combined effect from relatively young freshly-emitted air masses.

Our measurements yield on-road emissions $\mathrm{PM}_{1 \text { org }} / \mathrm{CO}$ ratios of $4.4 \pm 3 \mu \mathrm{g} / \mathrm{m}^{3} / \mathrm{ppm}$ (STP), which are well within the range of the observed early morning ratios at the surface sites $\mathrm{T} 0$ and CENICA. Our observed low OA/CO ratios within the city are in sharp contrast with the high values obtained by the aircraft measurements at near-and long-range distances from the urban area. In our on-road measurements of $\mathrm{PM}_{1 \text { org }}$, most of the mass are dominated by the fresh primary organic aerosol (POA) rather than by the oxygenated SOA fraction. The observed diurnal OA/CO ratios at PTP are somewhat closer to the freshly-emitted values at the surface sites but already with some indication of OA production.

\subsection{Ambient $\mathrm{CO}$ and $\mathrm{NO}_{\mathrm{x}}$ concentration analyses}

The Mexico City ambient air quality monitoring network, RAMA (for Red Automatica de Monitoreo Atmosferico), has continuously measured ambient criteria pollutant concentrations since 1986 (data available at http://www.sma. df.gob.mx/simat/). The network consists of 34 stations located in the metropolitan area. $\mathrm{CO}$ is measured by gas filter correlation/non-dispersive infrared detectors and $\mathrm{NO}_{\mathrm{x}}$ by chemiluminescence monitors.

Under the generally low boundary layer conditions that occur during early morning in the MCMA, ambient surface concentrations of $\mathrm{CO}$ and $\mathrm{NO}_{\mathrm{x}}$ and many VOCs are driven by traffic emissions. Using data from the RAMA monitoring network, we compared the long-term trends of early morning (6-9 AM) $\mathrm{CO}, \mathrm{NO}_{\mathrm{x}}$ and $\mathrm{CO} / \mathrm{NO}_{\mathrm{x}}$ average levels with the corresponding trends estimated from the gasoline vehicle fleet emissions in the official emissions inventory (Fig. 4). The $\mathrm{CO} / \mathrm{NO}_{\mathrm{x}}$ trends are estimated using the daily slope of a linear regression of $\mathrm{CO}$ and $\mathrm{NO}_{\mathrm{x}}$ early morning concentrations, rather than from instantaneous values of the $\mathrm{CO} / \mathrm{NO}_{\mathrm{x}}$ ratios. There are several reasons for using the slope of the daily correlation between $\mathrm{CO}$ and $\mathrm{NO}_{\mathrm{x}}$ early morning levels in the trend analysis: 1) this is the period of maximum on-road vehicle activity during the day and of maximum ambient concentrations of pollutants from these sources; 2) the high seasonal variability of the mixing height on ambient pollutant levels (observed in Fig. 4) does not affect their ratio; 3 ) the loss of emitted $\mathrm{NO}_{\mathrm{x}}$ due to photochemical conversion and depositional processes are minimal due to relatively low photochemical activity; 4) off-road vehicle activity is likely small during this period, minimizing its influence in ambient levels; and 5) the transport of regional levels of these pol-
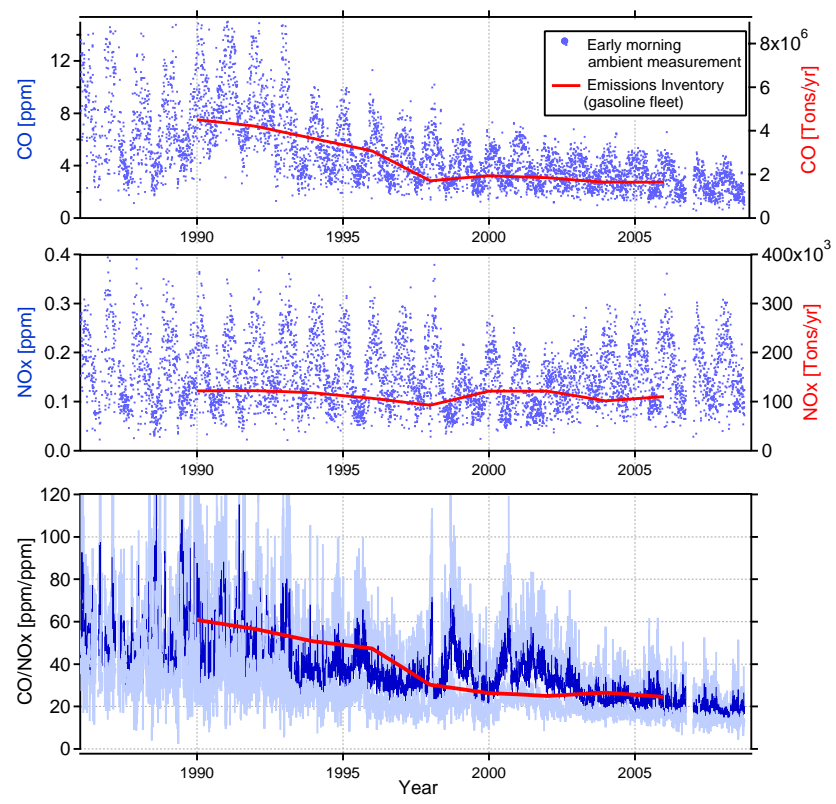

Fig. 4. Comparison of early morning ambient average $\mathrm{CO}, \mathrm{NO}_{\mathrm{x}}$ and $\mathrm{CO} / \mathrm{NO}_{\mathrm{x}}$ trends with official emissions estimates from the gasoline vehicle fleet in Mexico City (SMA, 2008a). Dark-blue and lightblue colored lines in the $\mathrm{CO} / \mathrm{NO}_{\mathrm{x}}$ levels represent the average and the 1-sigma standard deviation of daily measurements from all monitoring stations, respectively.

lutants into the urban area would affect the intercept of the regression line, but not the slope.

Light-blue colored lines in the $\mathrm{CO} / \mathrm{NO}_{\mathrm{x}}$ levels in Fig. 4 represent the 1-sigma standard deviation of daily measurements from all continuous MCMA monitoring stations. The observed daily variability range of the $\mathrm{CO} / \mathrm{NO}_{\mathrm{x}}$ ratio represents the spatial variation of this quantity across the monitoring stations within the city. The early morning MCMA $\mathrm{CO} / \mathrm{NO}_{\mathrm{x}}$ ratio has decreased significantly over the last two decades at a rate of about $1.9 \mathrm{ppm} / \mathrm{ppm} /$ year. Overall, the decrease seems to have been driven by decreases in CO levels rather than by changes in $\mathrm{NO}_{\mathrm{x}}$ concentration. However, over the shorter time scale between 1999 and 2001, the relatively abrupt changes in the average $\mathrm{CO} / \mathrm{NO}_{\mathrm{x}}$ ratio seems to have been driven by changes in the early morning $\mathrm{NO}_{\mathrm{x}}$ ambient levels rather than by changes in CO levels. It is worth noted that for the first time Mexico set limits for lightduty gasoline vehicle exhaust limits in January 2000 implementing $\mathrm{NO}_{\mathrm{x}}$ emissions limits for 1990 and older models of $2500 \mathrm{ppm}, 1500 \mathrm{ppm}$ for 1991-1992 models, and $1200 \mathrm{ppm}$ for 1993 and later models. Moreover, 1993-1995 vehicles were obliged to replace their used three-way catalyst to meet the new exhausts limits. These mandated $\mathrm{NO}_{\mathrm{x}}$ emissions limits may have triggered the observed 1999-2001 $\mathrm{NO}_{\mathrm{x}}$ reductions. 
Countering the introduction of new and strengthening of existing emission standards, changes in the vehicle fleet composition are probably responsible for the apparent increase of $\mathrm{NO}_{\mathrm{x}}$ levels between 2000 and 2006. A comparison of fuel sales data between 2000 and 2006 from the latest emissions inventory (SMA, 2008a) shows that gasoline fuel sales increased about $1.8 \%$ annually on average whereas diesel fuel sales increased about $4 \%$ annually over that period. Since diesel vehicles emit much higher $\mathrm{NO}_{\mathrm{x}}$ than gasoline vehicles (e.g., Harley et al., 2005; Zavala et al., 2006), their relative contribution to overall $\mathrm{NO}_{\mathrm{x}}$ levels likely increased over time. This has also been directly observed in California from long-term analysis of $\mathrm{NO}_{\mathrm{x}}$ emissions measured in tunnel studies (Ban-Weiss et al., 2008). Other reasons that could contribute to the increase of $\mathrm{NO}_{\mathrm{x}}$ are the proliferation of air conditioning availability in private cars in Mexico City and faster deterioration in the NO removal efficiency by catalytic converters compared to VOCs and CO.

We also compared the morning $\mathrm{CO} / \mathrm{NO}_{\mathrm{y}}$ ratios at PTP (where sampled air masses were already well-mixed urban emissions) with ambient $\mathrm{CO} / \mathrm{NO}_{\mathrm{x}}$ ratios measured during the morning traffic peak and the measured on-road ratios. Typical molar $\mathrm{CO} / \mathrm{NO}_{\mathrm{y}}$ ratios observed in the morning at PTP were 20. Since morning $\mathrm{NO}_{\mathrm{x}} / \mathrm{NO}_{\mathrm{y}}$ ratios are typically very close to 1 at urban MCMA ground sites and there is relatively little deposition of $\mathrm{NO}_{\mathrm{y}}$ in the first few hours of emissions (Wood et al., 2009; Kleinman et al., 2008), the $\mathrm{CO} / \mathrm{NO}_{\mathrm{y}}$ ratio observed at PTP can be compared on an equal basis with the $\mathrm{CO} / \mathrm{NO}_{\mathrm{x}}$ ratios from the RAMA monitoring sites shown in Fig. 4. Thus, there is good agreement in the $\mathrm{CO} / \mathrm{NO}_{\mathrm{x}}$ ratio between three sets of data: the RAMA monitoring data, the PTP ambient data, and on-road data.

It is interesting to note that the small apparent MCMA mobile EI overestimations in both $\mathrm{CO}$ and $\mathrm{NO}$ emissions in Fig. 3 do not contradict the results from our trend analysis of the ambient $\mathrm{CO} / \mathrm{NO}_{\mathrm{x}}$ ratio against the corresponding ratio from the inventory. The ratio in the inventory seems to be within the observed ambient value uncertainties, although a probable slight overestimation occurs concurrently in both $\mathrm{CO}$ and $\mathrm{NO}_{\mathrm{x}}$ emission estimates. While we cannot evaluate the magnitude of the official $\mathrm{CO}$ and $\mathrm{NO}_{\mathrm{x}}$ emissions estimates from Fig. 4, we can evaluate their trends. Overall, changes in the $\mathrm{CO}$, and to some extent $\mathrm{NO}_{\mathrm{x}}$, emissions estimates seem to have been well captured in the emissions inventory for the gasoline vehicle fleet. Official estimates are reported every two years, so it is harder to capture the higher (as compared to $\mathrm{CO}$ ) year-to-year variability observed in the $\mathrm{NO}_{\mathrm{x}}$ ambient levels. However, we can evaluate the magnitude of the $\mathrm{CO} / \mathrm{NO}_{\mathrm{x}}$ ratio in the emissions inventory. The agreement with the observed ratio seems remarkably good both in trend and magnitude, suggesting that the ratio of $\mathrm{CO}$ and $\mathrm{NO}_{\mathrm{x}}$ emissions in the official emissions inventory is well estimated.

\subsection{Impact of older, high emission vehicles}

It is crucial to assess the rate at which the older vehicles are removed from the fleet in Mexico City because 1990 model and earlier vehicles do not have emission control systems, 1991-1992 vehicles have two-way catalytic converters, and only 1993 and newer vehicles have three-way catalytic converters. Figure 5 indicates that the total size of the vehicle fleet had an impressive increase of $75 \%$ (10.7\%/year) between 2000 and 2006. Figure 5 also shows that the percentage of vehicles older than 1998 has been significantly and systematically reduced between 2000 and 2006. However, analysis of the vehicle fleet age shown in Fig. 5 indicates that this reduction has been caused mostly by an increase in the number of newer 1999-2006 vehicles, rather than by a large decrease in the number of older vehicles. Thus, the relative large decrease of the percentage of vehicles without emissions controls systems is not very pertinent for explaining the changes of emissions from mobile sources in that period. The rate of removal of older vehicles from the vehicle fleet is much more relevant. Figure 6 shows the percentage change of the number of 1990 and older vehicles (that is, vehicles without emissions control technologies) between 2000 and 2006. For example, 1982 and older vehicles decreased by about $14 \%$ (2\%/year) and the total number of vehicles 1990 and older decreased by only 9\% (1.3\%/year) between 2000 and 2006. Figure 6 shows that the highest removal rates within this group of high-polluting vehicles are concentrated mostly at the very end ( $>22$ years old) of the age distribution.

Long-term analysis of ambient pollutants (Stephens et al., 2008; Zavala et al., 2009b) and Fig. 1 in this work indicate that despite the impressive $75 \%$ increase of the vehicle fleet over the 2000-2006 period, the ambient concentrations of $\mathrm{CO}$ and $\mathrm{NO}_{\mathrm{x}}$ have not increased proportionally. The relatively insensitive responses of $\mathrm{CO}$ and $\mathrm{NO}_{\mathrm{x}}$ levels to the large increases in the vehicle fleet can be related to the relatively low emissions from new vehicles introduced and the observed low removal rates of high-polluting vehicles. Remote sensing studies have shown that 1990 and older MCMA vehicles have 4-7 times higher $\mathrm{CO}$ and VOC and 3-5 times higher NO fuel-based emission factors compared to 2000 model vehicles (Schifter et al., 2005). Such differences in emission factor ratios for 1990 and older vehicles and post2000 models are expected to have increased even more between 2000 and 2006 due to improvements in newer vehicle technology. This indicates that an emission-based air quality improvement strategy targeting a significant reduction in the emissions from mobile sources should be designed to increase the removal rate of 1990 and older vehicles. 

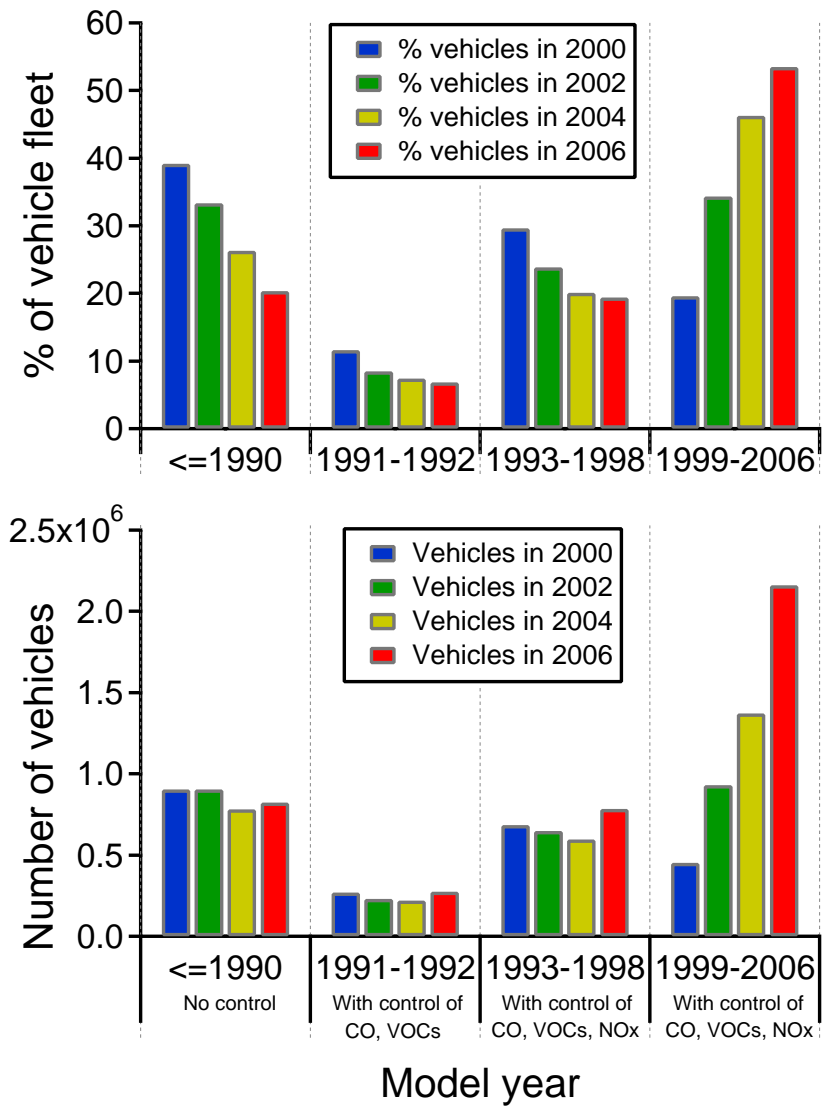

Fig. 5. Upper panel: evolution of the model-year distributions of the gasoline vehicle fleets (in \%) from 2000 to 2006. Lower panel: evolution of the size of the gasoline vehicle fleet by model-year in the same period. Data adapted from SMA (2008a).

\section{Conclusions}

We have presented measured on-road, fleet-average exhaust emission factors obtained with the Aerodyne mobile laboratory in Mexico City in 2006. We compared the 2006 MCMA on-road emission measurements with those obtained in 2003 using essentially the same measurement techniques and analysis methods. The observed changes for $\mathrm{NO}_{\mathrm{x}}$ emission factors between 2003 and 2006 were within the measured variability ranges. On-road emission factors of aldehydes and aromatics species were reduced between 2003 and 2006, with reductions in these VOC species observed under most driving conditions.

On-road MCMA CO and $\mathrm{NO}_{\mathrm{x}}$ fuel-based fleet emissions factors measured with the mobile laboratory in 2006 agree remarkably well with those measured in the same year by cross-road remote sensing study. Comparison of the observed trends of fuel-based emission factors in Mexico City with those obtained by remote sensing in several cities in the US indicates much smaller annual average reductions of emissions factors in Mexico City. An analysis of the changes of the MCMA vehicle fleet age shows that the smaller an-

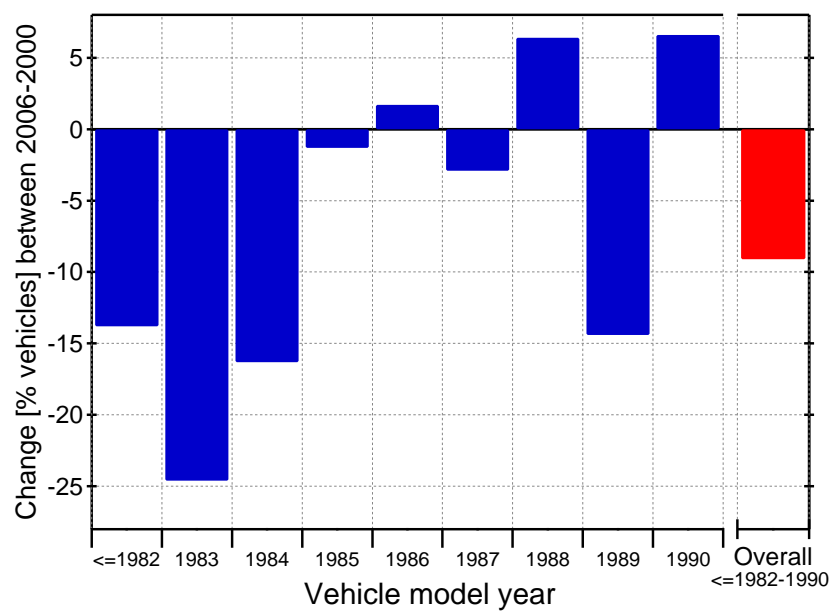

Fig. 6. Percentage change in the number of vehicles models-year 1990 to $<=1982$ (that is, vehicles without emission control devices) between 2006 and 2000 in Mexico City. Data adapted from SMA (2008a).

nual average reductions of the fuel-based emissions factors in Mexico City is probably a consequence of the lower removal rates of older vehicles, particularly those without emissions control technology.

We have evaluated the gasoline vehicle fleet emissions estimated in the bottom-up MCMA criteria and toxic emissions inventories using our on-road measurements and available data from cross-road remote sensing studies. We found slight overpredictions of mean estimates on the order of 20-28\% for $\mathrm{CO}$ and $14-20 \%$ for $\mathrm{NO}$ emissions, although these are within the range of measurement uncertainties. Using the observed range of the $\mathrm{VOC} / \mathrm{CO}$ mass ratios, a rough approximation of the on-road VOC emissions suggests an overall range between 1.4 and 1.9 smaller estimated mobile VOC emissions in the inventory. The larger range results partially from the large uncertainties in the estimation of the $\mathrm{VOC} / \mathrm{CO}$ ratio from remote sensing measurements. In contrast, estimated benzene and toluene mobile emissions in the inventory seem to be well within uncertainties of the corresponding emissions estimates based on the on-road emissions measurements. Aldehydes mobile emissions, however, seem to be underpredicted by factors of 3 for $\mathrm{HCHO}$ and 2 for $\mathrm{CH}_{3} \mathrm{CHO}$. Similarly, our estimates of annual emissions of organic mass from $\mathrm{PM}_{1}$ particles from the on-road measurements suggest a severe underprediction (larger than a factor of 4) of $\mathrm{PM}_{2.5}$ EI emissions from gasoline vehicles.

Our analyses indicate that the early morning ambient $\mathrm{CO} / \mathrm{NO}_{\mathrm{x}}$ ratio has decreased significantly over the last two decades at a rate of about $1.9 \mathrm{ppm} / \mathrm{ppm} / \mathrm{year}$ and that the decrease has been driven by reductions in $\mathrm{CO}$ levels rather than by $\mathrm{NO}_{\mathrm{x}}$ concentration changes. Our analysis also suggests that the relative contribution of diesel vehicles to overall $\mathrm{NO}_{\mathrm{x}}$ levels has increased over time in Mexico City. The long-term 
analysis of ambient pollutants indicates that despite the impressive increase in the size of the vehicle fleet between 2000 and 2006, the early morning ambient concentrations of $\mathrm{CO}$ and $\mathrm{NO}_{\mathrm{x}}$ have not increased accordingly. We suggest that this has been partially due to the observed removal rates of older vehicles that do not have emissions control technologies and partially due to the much lower emissions from newer gasoline vehicles. This indicates that an emissionbased air quality improvement strategy targeting large reductions of emissions from mobile sources should be directed towards a significant increase of the removal rate of older, high-polluting, vehicles.

Acknowledgements. We are indebted to the large number of people involved in the MILAGRO field campaign as well as those involved in long-term monitoring in the Mexico City metropolitan area which made this study possible. We thank Francisco Hernández and Victor Hugo Páramo for their comments during the writing of the manuscript. This work was supported by the US Department of Energy's Atmospheric Sciences Program (DE-FG02-05ER63980 and DE-FG02-05ER63982), the US National Science Foundation's Atmospheric Chemistry Program (ATM-0528170 and ATM528227) and Mexico's Comisión Ambiental Metropolitana.

Edited by: S. Madronich

\section{References}

Ban-Weiss, G., McLaughlin, J., Harley, R., Lunden, M., Kirchstetter, T., Kean, A., Strawa, A., Stevenson, E., and Kendall, G.: Long-term changes in emissions of nitrogen oxides and particulate matter from on-road gasoline and diesel vehicles, Atmos. Environ., 42, 220-232, 2008.

Bishop, G. A., Starkey, J. R., Ihlenfeldt, A., Williams, W. J., and Stedman, D. H.: IR long-path photometry: a remote sensing tool for automotive emissions, Anal. Chem., 61(10), 671-677, 1989.

Bishop, G. and Stedman, D.: A decade of on-road emissions measurements, Environ. Sci. Technol., 42(5), 1651-1656, 2008.

Cadle, S. H., Gorse, R. A., Bailey, B. K., and Lawson, D. R.: Realworld vehicle emissions: a summary of the Eleventh Coordinating Research Council On-Road Vehicle Emissions Workshop, J. Air Waste Manage., 52(2), 220-236, 2002.

Cadle, S. H., Ayala, A., Black, K. N., Fulper, C. R., Graze, R. R., Minassian, F., Natarajan, M., Tennant, C. J., and Lawson, D. R.: Real-world vehicle emissions: a summary of the Sixteenth Coordinating Research Council On-Road Vehicle Emissions Workshop, J. Air Waste Manage., 57(2), 139-145, 2007.

DeCarlo, P. F., Dunlea, E. J., Kimmel, J. R., Aiken, A. C., Sueper, D., Crounse, J., Wennberg, P. O., Emmons, L., Shinozuka, Y., Clarke, A., Zhou, J., Tomlinson, J., Collins, D. R., Knapp, D., Weinheimer, A. J., Montzka, D. D., Campos, T., and Jimenez, J. L.: Fast airborne aerosol size and chemistry measurements above Mexico City and Central Mexico during the MILAGRO campaign, Atmos. Chem. Phys., 8, 4027-4048, 2008, http://www.atmos-chem-phys.net/8/4027/2008/.

de Foy, B., Fast, J. D., Paech, S. J., Phillips, D., Walters, J. T., Coulter, R. L., Martin, T. J., Pekour, M. S., Shaw, W. J., Kastendeuch, P. P., Marley, N. A., Retama, A., and Molina, L. T.: Basin- scale wind transport during the MILAGRO field campaign and comparison to climatology using cluster analysis, Atmos. Chem. Phys., 8, 1209-1224, 2008, http://www.atmos-chem-phys.net/8/1209/2008/.

Frey, H. and Zhao, Y.: Quantification of variability and uncertainty for air toxic emission inventories with censored emission factor data, Environ. Sci. Technol., 38(22), 6094-6100, 2004.

Fujita, E., Croes, B., Bennett, C., and Lawson, D.: Comparison of emission inventory and ambient concentration ratios of $\mathrm{CO}$, NMOG, and $\mathrm{NO}_{\mathrm{x}}$ in California's South Coast Air Basin, J. Air Waste Manage., 42, 264-276, 1992.

Garcia, A. R., Volkamer, R., Molina, L. T., Molina, M. J., Samuelson, J., Mellqvist, J., Galle, B., Herndon, S. C., and Kolb, C. E.: Separation of emitted and photochemical formaldehyde in Mexico City using a statistical analysis and a new pair of gas-phase tracers, Atmos. Chem. Phys., 6, 4545-4557, 2006, http://www.atmos-chem-phys.net/6/4545/2006/.

Harley, R., McKeen, S., Pearson, J., Rodgers, M., and Lonneman, W.: Analysis of motor vehicle emissions during the Nashville/Middle Tennessee Ozone Study, J. Geophys. Res., 106, 3559-3567, 2001.

Harley, R., Marr, L., Lehner, J., and Giddings, S.: Changes in motor vehicle emissions on diurnal to decadal time scales and effects on atmospheric composition, Environ. Sci. Technol., 39, 53565362, 2005.

Herndon, S. C., Jayne, J. T., Zahniser, M. S., Worsnop, D. R., Knighton, B., Alwine, E., Lamb, B. K., Zavala, M., Nelson, D. D., McManus, J. B., Shorter, J. H., Canagaratna, M. R., Onasch, T. B., and Kolb, C. E.: Characterization of urban pollutant emission fluxes and ambient concentration distributions using a mobile laboratory with rapid response instrumentation, Faraday Discuss., 130, 327-339, 2005.

Jazcilevich, A., García-Fragoso, A., García, A., Grutter, M., DiegoAyala, U., Lents, J., and Davis, N.: A vehicle emissions system using a car simulator and a geographical information system: Part 1, J. Air Waste Manage., 57(10), 1234-1240, 2007.

Jiang, M., Marr, L. C., Dunlea, E. J., Herndon, S. C., Jayne, J. T., Kolb, C. E., Knighton, W. B., Rogers, T. M., Zavala, M., Molina, L. T., and Molina, M. J.: Vehicle fleet emissions of black carbon, polycyclic aromatic hydrocarbons, and other pollutants measured by a mobile laboratory in Mexico City, Atmos. Chem. Phys., 5, 3377-3387, 2005, http://www.atmos-chem-phys.net/5/3377/2005/.

Kean, A. J., Harley R. A., and Kendall, G. R.: Effects of vehicle speed and engine load on motor vehicle emissions, Environ. Sci. Technol., 37, 3739-3746, 2003.

Kirchstetter, T. W., Singer, B. C., Harley, R. A., Kendall, G. R., and Traverse, M.: Impact of California reformulated gasoline on motor vehicle emissions. 1. Mass emissions rates, Environ. Sci. Technol., 33, 318-328, 1999.

Kleinman, L. I., Springston, S. R., Daum, P. H., Lee, Y.-N., Nunnermacker, L. J., Senum, G. I., Wang, J., Weinstein-Lloyd, J., Alexander, M. L., Hubbe, J., Ortega, J., Canagaratna, M. R., and Jayne, J.: The time evolution of aerosol composition over the Mexico City plateau, Atmos. Chem. Phys., 8, 1559-1575, 2008, http://www.atmos-chem-phys.net/8/1559/2008/.

Kolb, C. E., Herndon, S. C., McManus, J. B., Shorter, J. H., Zahniser, M. S., Nelson, D. D., Jayne, J. T., Canagaratna, M. R., and Worsnop, D. R.: Mobile laboratory with rapid response instru- 
ments for real-time measurements of urban and regional trace gas and particulate distributions and emission source characteristics, Environ. Sci. Technol., 38, 5694-5703, 2004.

Lei, W., de Foy, B., Zavala, M., Volkamer, R., and Molina, L. T.: Characterizing ozone production in the Mexico City Metropolitan Area: a case study using a chemical transport model, Atmos. Chem. Phys., 7, 1347-1366, 2007,

http://www.atmos-chem-phys.net/7/1347/2007/.

Lei, W., Zavala, M., de Foy, B., Volkamer, R., Molina, M. J., and Molina, L. T.: Impact of primary formaldehyde on air pollution in the Mexico City Metropolitan Area, Atmos. Chem. Phys., 9, 2607-2618, 2009,

http://www.atmos-chem-phys.net/9/2607/2009/.

McGaughey, G., Desai, N., Allen, D., Seila, R., Lonneman, W., Fraser, M., Harley, R., Pollack, A., Ivy, J., and Price, J.: Analysis of motor vehicle emissions in a Houston tunnel during the Texas Air Quality Study 2000, Atmos. Environ., 38, 3363-3372, 2004.

Molina, L. T., Kolb, C. E., de Foy, B., Lamb, B. K., Brune, W. H., Jimenez, J. L., Ramos-Villegas, R., Sarmiento, J., ParamoFigueroa, V. H., Cardenas, B., Gutierrez-Avedoy, V., and Molina, M. J.: Air quality in North America's most populous city overview of the MCMA-2003 campaign, Atmos. Chem. Phys., 7, 2447-2473, 2007,

http://www.atmos-chem-phys.net/7/2447/2007/.

Molina, L. T., Madronich, S., Gaffney, J. S., and Singh, H. B.: Overview of MILAGRO/INTEX-B Campaign, IGAC Newsletter, Issue No. 38, 2-15, April 2008.

NARSTO, (North American Research Strategy for Tropospheric Ozone): Improving emissions inventories for effective air quality management across North America, a NARSTO assessment, NARSTO-05-001, 2005.

Parrish, D. D., Trainer, M., Hereid, D., Williams, E., Olszyna, K., Harley, R., Meagher, J., and Fehsenfeld, F.: Decadal change in carbon monoxide to nitrogen oxide ratio in US vehicular emissions, J. Geophys. Res., 107(D12), 4140, doi:10.1029/2001JD000720, 2002.

Pierson, W., Gertler, A., Robinson, N., Sagebiel, J., Zielinska, B., Bishop, G., Stedman, D., Zweidinger, R., and Ray W.: Realworld automotive emissions-Summary of studies in the Fort McHenry and Tuscarora mountain tunnels, Atmos. Environ., 30, 2233-2256, 1996.

Pokharel S., Bishop G., and Stedman D.: An on-road motor vehicle emissions inventory for Denver: an efficient alternative to modeling, Atmos. Environ., 36, 5177-5184, 2002.

Popp, P. J., Bishop, G. A., and Stedman, D. H.: Development of a high-speed ultraviolet spectrometer for remote sensing of mobile source nitric oxide emissions, J. Air Waste Manage., 49, 14631468, 1999.

Rogers, T. M., Grimsrud, E. P., Herndon, S. C., Jayne, J. T., Kolb, C. E., Allwine, E., Westberg, H., Lamb, B. K., Zavala, M., Molina, L. T., Molina, M. J., and Knighton, W. B.: On-road measurements of volatile organic compounds in the Mexico City Metropolitan Area using Proton Transfer Reaction Mass Spectrometry, Int. J. Mass Spectrom., 252, 26-37, 2006.

Querol, X., Pey, J., Minguillón, M. C., Pérez, N., Alastuey, A., Viana, M., Moreno, T., Bernabé, R. M., Blanco, S., Cárdenas, B., Vega, E., Sosa, G., Escalona, S., Ruiz, H., and Artíñano, B.: PM speciation and sources in Mexico during the MILAGRO-2006 Campaign, Atmos. Chem. Phys., 8, 111-128, 2008, http://www.atmos-chem-phys.net/8/111/2008/.

Salcedo, D., Onasch, T. B., Dzepina, K., Canagaratna, M. R., Zhang, Q., Huffman, J. A., DeCarlo, P. F., Jayne, J. T., Mortimer, P., Worsnop, D. R., Kolb, C. E., Johnson, K. S., Zuberi, B., Marr, L. C., Volkamer, R., Molina, L. T., Molina, M. J., Cardenas, B., Bernabé, R. M., Márquez, C., Gaffney, J. S., Marley, N. A., Laskin, A., Shutthanandan, V., Xie, Y., Brune, W., Lesher, R., Shirley, T., and Jimenez, J. L.: Characterization of ambient aerosols in Mexico City during the MCMA-2003 campaign with Aerosol Mass Spectrometry: results from the CENICA Supersite, Atmos. Chem. Phys., 6, 925-946, 2006,

http://www.atmos-chem-phys.net/6/925/2006/.

Schifter, I., Diaz, L., Duran, J., Guzman, E., Chavez, O., and LopezSalinas, E.: Remote sensing study of emissions from motor vehicles in the metropolitan area of Mexico City, Environ. Sci. Technol., 37, 395-401, 2003.

Schifter, I., Díaz, L., Múgica, V., and López-Salinas, E.: Fuel-based motor vehicle emission inventory for the metropolitan area of Mexico City, Atmos. Environ., 39(5), 931-940, 2005.

Schifter, I., Díaz, L., Rodríguez, R., Durán, J., and Chávez, O.: Trends in exhaust emissions from in-use Mexico City vehicles, 2000-2006. A remote sensing study, Environ. Monit. Assess., 137, 459-470, doi:10.1007/s10661-007-9781-4, 2008.

Singer, B. C. and Harley, R. A.: A fuel-based motor vehicle emission inventory, J. Air Waste Manage., 46, 581-593, 1996.

Singer, B. C., Kirchstetter, T. W., Harley, R. A., Kendall, G. R., and Hesson, J. M.: A Fuel-Based Approach to Estimating Motor Vehicle Cold Start Emissions, J. Air Waste Manage., 49, 125135, 1999.

Singer, B. C. and Harley, R. A.: A fuel-based inventory of motor vehicle exhaust emissions in the Los Angeles Area during Summer 1997, Atmos. Environ., 34, 1783-1795, 2000.

SMA (Secretaria del Medio Ambiente del Distrito Federal): Inventario de emisiones criterio para el año de 2006 de la Zona Metropolitana del Valle de México, Secretaría del Medio Ambiente, Gobierno de México, México, available at: http://www. sma.df.gob.mx/, 2008a.

SMA (Secretaria del Medio Ambiente del Distrito Federal): Inventario de emisiones toxicas para el año de 2006 de la Zona Metropolitana del Valle de México, Secretaría del Medio Ambiente, Gobierno de México, México, available at: http://www. sma.df.gob.mx/, 2008b.

Stephens, S., Madronich, S., Wu, F., Olson, J. B., Ramos, R., Retama, A., and Muñoz, R.: Weekly patterns of México City's surface concentrations of $\mathrm{CO}, \mathrm{NO}_{\mathrm{x}}, \mathrm{PM}_{10}$ and $\mathrm{O}_{3}$ during 19862007, Atmos. Chem. Phys., 8, 5313-5325, 2008,

http://www.atmos-chem-phys.net/8/5313/2008/.

Stone, E. A., Snyder, D. C., Sheesley, R. J., Sullivan, A. P., Weber, R. J., and Schauer, J. J.: Source apportionment of fine organic aerosol in Mexico City during the MILAGRO experiment 2006, Atmos. Chem. Phys., 8, 1249-1259, 2008, http://www.atmos-chem-phys.net/8/1249/2008/.

Whitfield, J. K. and Harris, D. B.: Comparison of heavy-duty diesel emissions from engine and chassis dynamometers and on-road testing, in: Eighth CRC On-Road Vehicle Emissions Workshop, San Diego, CA., Coordinating Research Council, 2-8, 1998.

Wood, E. C., Herndon, S. C., Onasch, T. B., Kroll, J. H., Canagaratna, M. R., Kolb, C. E., Worsnop, D. R., Neuman, J. A., Seila, R., Zavala, M., and Knighton, W. B.: A case study of 
ozone production, nitrogen oxides, and the radical budget in Mexico City, Atmos. Chem. Phys., 9, 2499-2516, 2009, http://www.atmos-chem-phys.net/9/2499/2009/.

Wöhrnschimmel, H., Zuk, M., Martínez-Villa, G., Cerón, Cárdenas, B., Rojas-Bracho, L., and Fernández-Bremauntz, A.: The impact of a Bus Rapid Transit system on commuters' exposure to Benzene, $\mathrm{CO}, \mathrm{PM}_{2.5}$ and $\mathrm{PM}_{10}$ in Mexico City, Atmos. Environ., 42, 8194-8203, 2008.

Zavala, M., Herndon, S. C., Slott, R. S., Dunlea, E. J., Marr, L. C., Shorter, J. H., Zahniser, M., Knighton, W. B., Rogers, T. M., Kolb, C. E., Molina, L. T., and Molina, M. J.: Characterization of on-road vehicle emissions in the Mexico City Metropolitan Area using a mobile laboratory in chase and fleet average measurement modes during the MCMA-2003 field campaign, Atmos. Chem. Phys., 6, 5129-5142, 2006, http://www.atmos-chem-phys.net/6/5129/2006/.

Zavala, M., Herndon, S. C., Wood, E. C., Jayne, J. T., Nelson, D. D., Trimborn, A. M., Dunlea, E., Knighton, W. B., Mendoza, A., Allen, D. T., Kolb, C. E., Molina, M. J., and Molina, L. T.: Comparison of emissions from on-road sources using a mobile laboratory under various driving and operational sampling modes, Atmos. Chem. Phys., 9, 1-14, 2009a, http://www.atmos-chem-phys.net/9/1/2009/.
Zavala, M., Lei, W., Molina, M. J., and Molina, L. T.: Modeled and observed ozone sensitivity to mobile-source emissions in Mexico City, Atmos. Chem. Phys., 9, 39-55, 2009b, http://www.atmos-chem-phys.net/9/39/2009/.

Zhang, Q., Jimenez, J. L., Canagaratna, M. R., Allan, J. D., Coe, H., Ulbrich, I., Alfarra, M. R., Takami, A., Middlebrook, A. M., Sun, Y. L., Dzepina, K., Dunlea, E., Docherty, K., DeCarlo, P. F., Salcedo, D., Onasch, T., Jayne, J. T., Miyoshi, T., Shimono, A., Hatakeyama, S., Takegawa, N., Kondo, Y., Schneider, J., Drewnick, F., Borrmann, S., Weimer, S., Demerjian, K., Williams, P., Bower, K., Bahreini, R., Cottrell, L., Griffin, R. J., Rautiainen, J., Sun, J. Y., Zhang, Y. M., and Worsnop, D. R.: Ubiquity and dominance of oxygenated species in organic aerosols in anthropogenically-influenced Northern Hemisphere midlatitudes, Geophys. Res. Lett., 34, L13801, doi:13810.11029/12007GL029979, 2007.

Zhao, Y. and Frey, H.: Development of probabilistic emission inventories of air toxics for Jacksonville, Florida, USA, J. Air Waste Manage., 54, 1405-1421, 2004. 